Шевченко Л. С., д.е.н., професорка

Національний юридичний університет

імені Ярослава Мудрого

м. Харків, Украӥна

DOI: https://doi.org/10.30525/978-9934-26-028-5-35

\title{
ЦИФРОВА ТРАНСФОРМАЦІЯ БІЗНЕСУ В УМОВАХ КАДРОВИХ ОБМЕЖЕНЬ
}

3 позицій системного аналізу цифрову трансформацію бізнесу слід розглядати: по-перше, як фундаментальні зміни в технологіях, формах і способах людської діяльності; по-друге, як стратегічні зміни, що передбачають створення цифрових стратегій організацій. Дослідники цифровізації найчастіше аналізують нові бізнес-моделі, які були створені 3 розвитком цифрових технологій (наприклад, онлайн-комерцію), оцифровування частини традиційного бізнесу; цифровізацію внутрішніх операцій організацій, транзакцій між організаціями та між окремими особами. За даними McKinsey \& Company, ті підприємства, які вдаються до цифровізації, досягають зростання виручки більш ніж на 7\% порівняно з іншими в галузі, і майже на 6\% більше показник EBITDA [1]. Цифровізовані підприємства мають також інші переваги: 78\% із них краще запускають нові продукти чи послуги або вирощують стартапи; 62\% швидше виходять на ринок, у тому числі через цифровий маркетинг і персоналізацію; $60 \%$ ефективніше управляють витратами через здешевлення технологічних експериментів [2].

Цифрові перетворення бізнесу відбуваються під впливом зовнішнього технологічного, економічного і соціального середовища, але 3 урахуванням внутрішніх організаційних ресурсів, культури, структури і системи організації. I перша проблема, 3 якою стикається практично кожна бізнес-організація, - це внутрішні обмеження цифровізації бізнесу.

Теорія обмежень системи була розроблена у 1980-х рр. ізраїльським ученим Е. Голдраттом (Е. Goldratt). У нашому 
випадку це філософія управління, в основі якої лежить розуміння того, що успішність бізнесу (можливість постійно збільшувати прибуток) зумовлюється ефективністю / продуктивністю його обмежень - фізичних (матеріальних, виробничих), фінансових, ринкових, людських, часових, політики ведення бізнесу. При цьому чим швидше будуть виявлені обмеження, тим більш обгрунтованими будуть рішення щодо розвитку бізнесу та зростання його продуктивності. Обмеженнями можна управляти.

Здійснюючи цифрову трансформацію бізнесу, найпершу увагу слід приділити кадровим обмеженням, які чи не найбільше гальмують розвиток організації. Річ у тім, що в умовах цифровізації бізнесу змінюються вимоги до ключових компетентностей персоналу. Широке використання цифрових технологій потребує від персоналу володіння загальними, комплементарними i професійними IT-навичками. Загальні навички - це використання цифрових технологій у повсякденній роботі, зокрема, отримання доступу до інформації через Інтернет або використання програмного забезпечення для вирішення стандартних завдань. Комплементарні навички повинні забезпечити виконання нових завдань, наприклад, використання соціальних мереж для взаємодії з клієнтами, бізнес-планування, аналіз «великих даних» та ін. Професійні навички - розробка додатків, навички програмування тощо - як правило, є прерогативою фахівців у сфері IT [3, с. 380]. Дослідження McKinsey свідчать про те, що в Свропі до 2030 р. робочий час, проведений із використанням інноваційних технологічних навичок, збільшиться на 20\%, а з використанням базових технологічних компетентностей - на 65\%. Відповідно до цього ж дослідження, за подальші 10 років 90\% робочих місць потребуватимуть цифрових навичок [4]. Загалом «цифрова» грамотність (компетентність) визнана ЄС однією 38 ключових компетентностей для повноцінного життя та діяльності.

Що ми маємо нараз? По-перше, цифрові підприємства відчувають кадровий голод у представниках нової професії експертах у сфері цифрових технологій (цифрових експертах). Ідеться про фахівців, які мають такі професійні здібності й 
навички: інтелектуальний аналіз даних, інжиніринг та аналітика; програмування i веб-розробка, в тому числі початкова i внутрішня розробка; цифровий маркетинг, включаючи маркетинг впливу і маркетингову аналітику; цифровий дизайн, включаючи користувальницький інтерфейс (UX) i дизайн користувальницького інтерфейсу (UI); розробка мобільних додатків; штучний інтелект, у тому числі машинне навчання; гнучкі методи роботи; робототехніка та автоматизація. Особливо ціняться експерти 3 питань штучного інтелекту та експерти Agile, які мають спеціальні знання застосування гнучких методів роботи і найчастіше працюють у сфері інформаційних технологій. За даними WEF, у всьому світі сьогодні не більше 22 тис. спеціалістів рівня $\mathrm{PhD}$ у цій сфері й лише у США налічують понад 10 тис. відкритих вакансій.

По-друге, за відсутності масової цифрової грамотності не реалізованою залишається концепція «цифрових робочих місцы», згідно 3 якою компанії повинні використовувати цифрову трансформацію для узгодження технологій, співробітників i бізнес-процесів для підвищення операційної ефективності та досягнення цілей організації [5]. Утім саме створення цифрових робочих місць допомагає компаніям: підвищити мобільність персоналу й гнучкість робіт; знизити плинність кадрів; успішно конкурувати за талановитих працівників із новими компетентностями; вести ефективну перепідготовку персоналу. Цифрові робочі місця можуть включати системи управління навчанням (LMS) з метою наблизити навчання до співробітників і виміряти, наскільки швидко організація набуває нові навички та знання; оптимізувати затрати на персонал і покращити обслуговування клієнтів; поліпшити загальну систему управління. Цифрові робочі місця усувають перешкоди для доступу до даних i ресурсів, збільшують потік критично важливої інформації в рамках усього бізнесу, що дозволяє приймати рішення швидше й ефективніше, ніж будь-коли раніше.

Низка кадрових обмежень цифровізації бізнесу пов'язана 3 організацією праці. 3 одного боку, у цифровій економіці доволі 
недовговічними стають команди: їх склад починає швидко змінюватися, а працівники, особливо в сфері IКТ, працювати віртуально, відразу в кількох групах, у кількох містах і навіть країнах. Виникло навіть поняття «управління умовним персоналом». 3 другого боку, формується «гіг-економіка» - модель трудових відносин, що грунтується на короткострокових контрактах для виконання конкретних проєктів, можливо декількох одночасно, або навіть неформальних домовленостях. Зараз така модель є популярною у вигляді різних підробітків, часткової чи тимчасової зайнятості (Glovo, Uber, Bolt, Uklon та інші $є$ компаніями гіг-економіки). Але найбільше - серед IT-фахівців як фрілансерство 3 використанням робототехніки та когнітивних технологій. Оскільки працівники можуть працювати відразу на декількох роботодавців, менеджеру з персоналу важко формувати 3 них стабільні команди для досягнення бізнесрезультатів. Команди створюються тільки під конкретні потреби підприємств, а їх склад постійно змінюється [6].

Кадрові обмеження цифровізації спонукають HR-підрозділи фірм оптимізувати технології та інструменти підбору й оцінки ефективності персоналу, застосовувати алгоритми машинного навчання. Однак власники бізнесу повинні враховувати й інші чинники змін у сфері людських ресурсів. Наприклад, в умовах пандемії COVID-19 88\% керівників компаній в Україні та 77\% у світі визнали, що й надалі розвиватимуть інструменти цифрової співпраці й комунікацій; 73\% керівників бізнесу у світі і 39\% в Україні переконані, що віддалена робота розширила їхній доступ до кадрового резерву [7]. Потрібно інтегрувати HR-сферу в цифрові бізнес-процеси фірми.

\section{Література:}

1. Bubbles pop, downturns stop. URL: https://www.mckinsey.com/businessfunctions/strategy-and-corporate-finance/our-insights/bubbles-pop-downturns-stop.

2. Верховодов А. Цифрова трансформація та потреби бізнесу. URL: https://medium.com/@untone/цифрова-трансформація-та-потреби-бізнесу-5ba902 f5037d. 
3. Загребельная Н.С., Бостоганашвили Е.Р. Управление человеческими ресурсами в цифровой экономике. Экономика: вчера, сегодня, завтра. 2019. T. 9. № 1A. C. 374-384.

4. Україна $2030 \mathrm{E}$ - країна з розвинутою цифровою економікою. Український інститут майбутнього. URL: https://strategy.uifuture.org/kraina-z-rozvinutoyucifrovoyu-ekonomikoyu.html.

5. Rouse M. Digital workplace. URL: https://searchcontentmanagement.com/ definition/digital-workplace.

6. Власюк В. Не подобається? Звалюй! Або чому карантин оголив вразливість гіг-економіки. URL: https://www.epravda.com.ua/columns/2020/04/ 3/658901.

7. KPMG. Погляд керівників бізнесу в Україні 2020. Спецвипуск: COVID-19. URL: $\quad$ https://home.kpmg/content/dam/kpmg/ua/pdf/2020/10/CEO-Outlook_2020_ Ukraine.pdf. 